\title{
PENGEMBANGAN INSTRUMEN ASESMEN KETERAMPILAN MENULIS DAN BERPIKIR KRITIS PADA PELAJARAN IPA TERINTEGRASI SEKOLAH DASAR
}

\author{
M.K.D. Budiarta ${ }^{1}$, I.W.Lasmawan ${ }^{2}$, I.W. Widiana ${ }^{3}$ \\ ${ }^{123}$ Program Studi Pendidikan Dasar \\ Universitas Pendidikan Ganesha \\ Singaraja, Indonesia \\ e-mail: dewi.budiarta@undiksha.ac.id ${ }^{1}$, wayan.lasmawan@undiksha.ac.id ${ }^{2}$, \\ wayanwidiana85@undiksha.ac.id ${ }^{3}$
}

\begin{abstract}
Abstrak
Penelitian ini bertujuan untuk mengembangkan instrumen keterampilan menulis, dan berpikir kritis pada pelajaran IPA terintegrasi Sekolah Dasar yang valid dan reliabel. Penelitian ini menggunakan rancangan penelitian dan pengembangan dengan model 4-D. Model ini terdiri atas empat tahap utama yaitu define, design, develop, dan disseminate. Penelitian pengembangan ini menghasilkan pada instrumen pertama yaitu ketrampilan menulis dengan mengembangkan soal sebanyak 1 butir. Berdasarkan hasil dari perhitungan CVR, didapatkan 1 soal yang valid. Menurut expert instrument ketrampilan menulis IPA pada siswa kelas IV SD sebesar $\mathrm{r} 11=0,86$ (terkategori sangat tinggi). Instrumen kedua yaitu kemampuan berpikir kritis IPA berupa soal uraian sebanyak 10 butir. Selanjutnya dilakukan analisis uji validitas isi untuk instrumen kemampuan berpikir kritis IPA pada siswa kelas IV SD menggunakan CVR. Berdasarkan hasil perhitungan CVR didapatkan 10 butir instrumen yang valid dan tidak terdapat instrumen yang tidak valid. Selanjutnya perhitungan reliabilitas instrumen menurut expert instrumen kemampuan berpikir kritis IPA pada siswa kelas IV SD yaitu sebesar $\mathrm{r} 11=0,74$ (terkategori tinggi). Dengan demikian pengembangan instrumen keterampilan menulis dan berpikir kritis dalam penelitian ini dinyatakan valid dan reliabel serta dapat dijadikan contoh untuk mengukur serta mengembangkan instrumen keterampilan menulis dan instrumen berpikir kritis siswa kelas IV SD.
\end{abstract}

Kata kunci: Berpikir Kritis; Instrumen Asesmen; Keterampilan Menulis

\begin{abstract}
This study aims to develop a valid and reliable instrument of writing skills and critical thinking in integrated science lessons of elementary school. This study uses a research and development design with a 4-D model. This model consists of four main stages, namely define, design, develop, and disseminate. This development research resulted in the first instrument, namely writing skills by developing 1 item of question. Based on the results of the CVR calculation, 1 valid question was obtained. According to the expert instrument, science writing skills for fourth grade elementary school students were $r 11=0.86$ (very high category). The second instrument is the ability to critical thingkingin science in the form of a description of 10 items. Furthermore, the analysis of the content validity test for the science critical thinking ability instrument in the fourth grade of elementary school students was carried out using the CVR. Based on the results of the CVR calculation, there are 10 valid instruments and no invalid instruments. Furthermore, the calculation of the reliability of the instrument according to the expert instrument of science critical thinking skills in fourth grade elementary school students is $r 11=0.74$ (high category). Thus, science writing skills outcomes instruments and science critical thingking in this study was declared valid and reliable and could be used as an example to measure and develop science writing skills outcomes instruments and critical thingking in science instruments for fourth grade elementary school students.
\end{abstract}

Keywords: Asessment Instrument; Critical Thinking; Writing Skill 


\section{PENDAHULUAN}

Upaya dalam mencapai tujuan pendidikan yang optimal salah satunya adalah kualitas instrumen yang digunakan oleh guru agar mampu mengembangkan kemampuan berpikir siswa. Namun kenyataannya, instrumen yang digunakan guru terbatas pada bank soal maupun soal-soal latihan yang tersedia pada modul siswa. Guru lebih menekankan pada penguasaan konsep IPA dan belum dirancang untuk mengembangkan keterampilan berpikir tingkat tinggi. Instrumen yang telah tersedia tanpa adanya pengembangan oleh guru tersebut memiliki kualitas kurang baik.

Tuntutan zaman saat ini menjadikan seorang guru harus mengubah mindset tentang hasil pembelajaran dengan mencapai tujuan pembelajaran abad 21. Agar siswa mampu mencapai keterampilan Abad 21 maka guru harus memiliki instrumen yang relevan dengan memenuhi kebutuhan kemampuan berpikir siswa. Salah satu faktor yang dapat menimbulkan kemampuan berpikir rendah siswa dalam pembelajaran IPA Terintegrasi adalah kualitas instrumen yang kurang baik. Oleh sebab itu perlu adanya pengembangan instrumen untuk kemampuan keterampilan menulis dan berpikir kritis siswa.

Pembelajaran tematik di Sekolah Dasar (SD) dengan pembelajaran yang berbasis abad 21 masih perlu dievaluasi masih terbatas alat evaluasi atau instrumen asesmen peserta didik, masih banyak guru melakukan penilaian hanya sebatas hafalan siswa dikarenakan kesulitan yang guru dalam mengembangkan instrumen asesmen. Rosyida, Zubaidah, \& Mahanal (2016) mengemukakan bahwa pengembangan keterampilan menulis dan berpikir kritis dalam pembelajaran di sekolah belum sepenuhnya diberdayakan.

Dalam rangka mencapai tujuan tersebut, sekolah merupakan salah satu wadah yang bertanggungjawab untuk mengembangkan semua potensi, kreativitas, keterampilan-keterampilan yang ada pada diri siswa. Salah satu karakteristik potensi peserta didik yang perlu diperhatikan guru yaitu adanya perbedaaan individu dalam hal keterampilan menulis. Keterampilan menulis merupakan salah satu kompetensi dasar yang dikembangkan dalam pembelajaran bahasa Indonesia. Keterampilan menulis menjadi salah satu keterampilan yang wajib dikuasai oleh siswa. Keterampilan menulis merupakan keterampilan yang harus dilatih atau dibelajarkan, bukan keterampilan yang diperoleh secara otomatis atau langsung. Hal ini sejalan dengan pendapat Qostantia (2016) yang menyatakan bahwa kemampuan menulis seseorang bukan dibawa sejak lahir, melainkan diperoleh melalui proses pembelajaran.

Kemampuan menulis siswa yang berbeda-beda menuntut guru untuk membuat atau memiliki instrumen asesmen khusus yang dapat menilai perkembangan kemampuan menulis siswa. Hal tersebut dapat dilakukan jika instrumen penilaian yang digunakan dalam pembelajaran menulis tidak hanya mencakup penilaian hasil saja, tetapi juga penilaian proses. Selain itu, instrumen asesmen keterampilan menulis juga harus disusun berdasarkan pada kriteria tertentu dan disesuaikan dengan kompetensi yang akan dicapai (Febriyanti, Harsiati, \& Dermawan, 2017).

Selain keterampilan menulis, keterampilan berpikir kritis juga sangat penting bagi siswa karena salah satunya menunjang dalam proses inovasi, khususnya untuk mengembangkan kapasitas intelektual siswa dalam proses pembelajaran. Proses berpikir kritis siswa memerlukan waktu untuk berkembang yang dipengaruhi oleh konsep intelektual yang diterima pada saat pembelajaran. Proses pembelajaran yang dilaksanakan guru dirancang untuk mengembangkan keterampilan berpikir siswa. Komponen pembelajaran seperti metode, media, RPP, dan alat penilaian harus mendukung dalam mengembangkan kemampuan berpikir kritis siswa. Metode dan model 
pembelajaran yang dapat meningkatkan kemampuan berpikir kritis siswa.

Rendahnya keterampilan berpikir kritis dan kreatif lulusan pada sekolah dasar sampai dengan perguruan tinggi di Indonesia masih sering dikeluhkan (Reta, 2012). Oleh karena itu, dibutuhkan asesmen yang mampu meningkatkan keterampilan menulis dan berpikir kritis siswa. Kualitas pembelajaran ditentukan salah satunya oleh kualitas asesmen yang dilakukan oleh guru dalam proses pembelajaran (Kusairi, 2012). Instrumen asesmen memegang peran penting untuk menunjang proses pembelajaran. Peran tersebut tidak bisa dilepaskan dari fungsi instrumen itu sendiri, yaitu untuk mengukur tingkat keberhasilan belajar siswa. Dari hasil pengukuran, guru dapat mengetahui kelemahan dan kekurangan siswa. Instrumen penilaian merupakan bagian integral dari suatu proses penilaian dalam pembelajaran, apa yang hendak diukur terkait dengan ketersediaan alat ukur yang dikembangkan, apa yang diukur dalam pembelajaran juga menentukan kualitas pembelajaran (Khaerunnnisa \& Pamungkas, 2018). Perlu disadari bahwa kegiatan evaluasi dalam pembelajaran akan lebih berguna dengan gagasan yang meliputi setiap keterampilan yang membutuhkan lebih dari sekadar mengingat atau menghafal informasi (Yen \& Halili, 2015). Kemampuan berpikir kritis dilndonesia, masih belum maksimal dibelajarkan. Hal ini terlihat dari, $78 \%$ siswa Indonesia hanya dapat mengerjakansoal-soal IPA yang berkategori rendah, yaitu hanya mengetahui atau hafalan (Rahayuni, 2016). Rendahnya kemampuan berpikir kritis siswa bisa terlihat dari ketika guru meminta siswa untuk memberi argumen.

Berdasarkan studi pendahuluan peneliti terhadap guru SD kelas IV Gugus Jenderal Sudirman, dapat diketahui bahwa kemampuan keterampilan menulis dan berpikir kritis masih lemah. Hal ini disebabkan karena 1) metode pembelajaran yang masih terpusat pada guru sehingga siswa cenderung pasif dan tidak mempunyai kesempatan untuk berpikir, 2) belum ada instrumen asesmen untuk mengukur keterampilan menulis dan kemampuan berpikir kritis siswa kelas IV Sekolah Dasar pada pembelajaran tematik, dan 3) sebagian besar di sekolah, baik pada testengah semester maupun tes akhir semester umumnya mengunakan tes pilihan ganda biasa. Jadi, tes pilihan ganda masih merupakan primadona dalam mendapatkan data prestasi belajar IPA siswa. Kenyataan bahwa tes pilihan ganda yang digunakan di SD untuk tes hasil belajar mata pelajaran IPA baru mengukur kemampuan mengingat, memahami, dan menerapkan.

Perlu diketahui bahwa model penilaian juga berpengaruh terhadap kemampuan berpikir siswa. Kurikulum memiliki potensi yang kaya untuk mengembangkan keterampilan berpikir tingkat tinggi peserta didik. Guru harus merencanakan dengan baik dan melibatkan peserta didik dalam kegiatan pembelajaran yang dapat mendorong dan mengembangkan kemampuan berpikir tingkat tinggi tersebut. Penilaian dapat diimplementasikan untuk membantu siswa dalam meningkatkan kemampuan berpikir tingkat tinggi mereka (Istiyono, Mardapi, \& Suparno, 2014). Hal ini didukung pendapat lain, bahwa pertanyaan berpikir tingkat tinggi dapat mendorong siswa untuk berpikir secara mendalam tentang materi pelajaran sehingga tes kemampuan berpikir tingkat tinggi dapat memberikan rangsangan kepada siswa untuk mengembangkan kemampuan berpikir tingkat tinggi juga.

Mengingat pentingnya instrumen penilaian maka diperlukan instrumen pembelajaran yang dapat memenuhi kriteria kemampuan keterampilan menulis dan berpikir kritis dalam penyelesaian masalah yang diberikan. Instrumen penilaian yang dibuat harus merangsang siswa agar siswa terampil dalam belajar dan berpikir kritis. Pengembangan instrumen assesmen bukanlah hal yang baru dalam pendidikan, sudah banyak penelitian dan pengembangan mengenai instrumen 
penilaian diantaranya penelitian yang dilakukan oleh Setiawan \& Sa'dijah (2017) yang menghasilkan instrumen asesmen autentik kompetensi pada ranah keterampilan untuk pembelajaran tematik di sekolah dasar layak dari segi validitas isi dan validitas konstruk, serta validitas dari segi kebahasaan. Penelitian yang dilakukan oleh Setiawan \& Sa'dijah (2017) menghasilkan instrumen assesmen yang memiliki syarat validitas dapat digunakan sebagai penilaian keterampilan berpikir kritis IPA untuk siswa kelas 4 SD.

Widoyoko (2014), mendefinisikan bahwa instrumen penilaian merupakan alat bantu yang digunakan oleh pendidik atau penilai untuk mengumpulkan data tentang karakteristik peserta didik dengan cara melakukan pengukuran. Dengan melakukan pengukuran akan diperoleh data yang objektif yang diperlukan untuk menilai hasil belajar peserta didik. Selain diperoleh data yang objektif, dengan menggunakan instrumen maka pekerjaan penilaian menjadi lebih mudah dan hasilnya lebih baik, dalam arti lebih cermat, lengkap, dan sistematis.

Penelitian mengenai instrumen assesmen yang dilakukan beberapa peneliti sebelumnya pada dasarnya dilakukan untuk menangani masalah yang sering dijumpai di lapangan. Oleh karena itu, peneliti sangat tertarik untuk melakukan penelitian mengenai "Pengembangan Instrumen Asesmen Keterampilan menulis dan Berpikir Kritis pada Pelajaran IPA Terintegrasi Sekolah Dasar".

\section{METODE}

Jenis penelitian yang digunakan
dalam penelitian ini adalah R\&D/Research and Development. Metode penelitian dan pengembangan atau yang biasa dikenal dengan menghasilkan produk tertentu, dan menguji keefektifan produk tersebut (Sugiyono, 2015). Metode Research and Development merupakan metode penelitian yang digunakan untuk menghasilkan produk tertentu, dan menguji keefektifan produk tersebut. Untuk dapat menghasilkan produk tertentu digunakan penelitian yang bersifat analisis kebutuhan dan untuk menguji keefektifan produk tersebut penelitian dilakukan secara bertahap/longitudinal agar hasil dari produk tersebut bisa bermanfaat bagi masyarakat luas (Sugiyono, 2015).

Model pengembangan dalam penelitian ini mengacu pada model penelitian dan pengembangan 4D (four$D$ ). Model penelitian dan pengembangan 4D terdiri atas 4 tahap utama, yaitu: define, design, develop, dan disseminate. Model pengembangan 4D dapat diadaptasikan menjadi 4P yaitu: pendefinisian, perancangan, pengembangan, dan penyebaran. Penerapan langkah utama dalam penelitian tidak hanya menurut versi asli namun disesuaikan dengan karakteristik subjek dan tempat asal examine (Trianto, 2010).

Subjek penelitian ini adalah expert, yakni terdiri dari dua dosen ahli dan tiga orang guru kelas IV SD untuk menilai hasil produk instrumen keterampilan menulis dan instrumen berpikir kritis. Expert akan menilai kisi-kisi, instrumen validasi ahli, dan produk yang dikembangkan.

Prosedur pengembangan instrumen pada penelitian ini terdiri dari empat tahap yaitu define, design, develop dan disseminate; namun tahap disseminate dilakukan secara terbatas karena situasi pandemi yang tidak memungkinkan dilakukannya kegiatan di lapangan.

Metode pengumpulan data yang digunakan pada penelitian ini adalah metode tes. Data yang dikumpulkan dalam penelitian ini adalah validitas dan reliabilitas keterampilan menulis dan berpikir kritis.

Data yang diperoleh dalam penelitian ini dianalisis sesuai dengan jenis dan kegunaannya dalam penelitian. Adapun data yang diperoleh berupa data deskriptif dari analisis kebutuhan, data deskriptif dari tahap pembuatan berupa deskripsi karakteristik produk, data hasil 
uji validitas produk, dan data hasil uji kepraktisan produk. Data yang diperoleh dari studi literatur dianalisis dengan mendeskripsikan setiap hasil yang diperoleh. Data yang diperoleh dari pembuatan produk dianalisis karakteristiknya dengan mendeskripsikan ciri dari produk tersebut.

Validasi expert yang diperoleh dari ahli dan praktisi akan menghasilkan data yang selanjutnya akan diuji validitasnya. Validasi dilakukan oleh ahli dan praktisi bertujuan untuk memastikan produk yang dikembangkan sudah sesuai dengan prosedur yang berlaku. Uji validitas isi yang dilakukan adalah Content Validity Ratio (CVR). Lawshe (1975) mengungkapkan bahwa CVR adalah sebuah pendekatan analisis isi yang bertujuan untuk mengetahui kesesuaian produk yang dikembangkan yang akan diukur berdasarkan judgement para ahli. Para ahli yang terlibat dalam proses judgment validitas isi ini antara lain: tiga orang expert dalam bidang pendidikan dan dua orang praktisi guru kelas V SD. Berikut ini rumus yang digunakan Lawshe untuk menghitung nilai CVR:

$$
C V R=\frac{n_{e}-\frac{N}{2}}{\frac{N}{2}}
$$

(Lawshe, 1975)

Keterangan:

$$
\begin{array}{ll}
C V R= & \text { rasio validitas isi } \\
n & =\text { jumlah ahli atau judgement } \\
& \text { pemberi nilai } \\
& \text { (penting/relevan/esensial) } \\
N & =\text { jumlah ahli atau judgement }
\end{array}
$$

Setelah butir yang valid teridentifikasi selanjutnya mencari nilai indeks validitas konten (CVI). Secara sederhana $\mathrm{CVI}$ merupakan rata-rata dari nilai CVR:

$$
C V I=\frac{\sum C V R}{\text { Jumlah Soal }}
$$

Validitas empiris merupakan suatu ukuran yang menunjukkan tingkat-tingkat kesahihan atau kecermatan suatu alat ukur atau instrumen dalam melakukan fungsi ukurnya berdasarkan fakta empiris atau pengalamannya. Instrumen yang valid mempunyai validitas tinggi, artinya instrumen tersebut dapat mengukur apa yang hendak diukur. Untuk menguji validitas empiris dari sebuah instrumen digunakan rumus korelasi product moment yang dikemukakan oleh Sugiyono (2015), yaitu:

$$
r_{x y}=\frac{N \sum X Y-\sum X \sum Y}{\sqrt{\left\{N \sum X^{2}-\left(\sum X\right)^{2}\right\}\left\{N \sum Y^{2}-\left(\sum Y\right)^{2}\right\}}}
$$

Keterangan:

$\boldsymbol{r}_{\boldsymbol{x} y}=$ koefisien korelasi product moment (antar X dan Y)

$X=$ skor dari variabel $X$ (skor butir)

$Y=$ skor dari variabel $Y$ (skor total)

$N$ = banyaknya data atau sampel

Uji reliabilitas dilakukan untuk setiap butir tes yang valid. Oleh karena skor yang digunakan dalam instrument tersebut menghasilkan skor politomi, maka reliabilitas akan dianalisis dengan menggunakan rumus Alpha Cronbach. Adapun rumus yang digunakan adalah sebagai berikut.

$$
r_{11}=\left(\frac{n}{n-1}\right)\left(1-\frac{\sum S_{i}^{2}}{S_{t}^{2}}\right)
$$

Keterangan :

$r_{11}=$ koefisien reliabilitas tes

$\mathrm{n}$ = banyaknya butir item yang dikeluarkan dalam tes

1 = bilangan konstan

$\Sigma S_{i}^{2}=$ jumlah varian skor dari tiap-tiap butir item

$\mathrm{S}_{\mathrm{t}}^{2}=$ varian total

Pada tingkat kesukaran soal tes esai/uraian, menggunakan rumus sebagai berikut. 
$\mathrm{TS}=\frac{\text { mean }}{\text { skor maksimumyang ditetapkan }}$ (Daryanto, 2012)

Dengan ketentuan interprestasi sebagai berikut.

Soal dengan p 0,00 sampai 0,30 adalah soal sukar

Soal dengan $p$ 0,30 sampai 0,70 adalah soal sedang

Soal dengan p 0.70 sampai 1,00 adalah soal mudah

\section{HASIL DAN PEMBAHASAN}

Validitas instrumen keterampilan menulis meliputi validitas isi yang didasari dari hasil validasi oleh pendapat ahli (expert judgment) dan praktisi pendidikan untuk pembelajaran IPA. Tahapan validasi awal untuk instrumen keterampilan menulis IPA adalah validasi ahli oleh 2 orang dosen ahli dan 3 orang praktisi dari guru sekolah dasar. Hasil dari expert judgment selanjutnya dilakukan analisis untuk mendapatkan indeks ratio validitasnya dengan melakukan perhitungan Content Validity Ratio (CVR). Rubrik penskoran untuk judges menggunakan skala 3 , yaitu relevan (3), kurang relevan (2), dan tidak relevan (1). Hasil uji validitas instrumen keterampilan menulis yang dikembangkan adalah 8 instrumen soal valid.

Validitas instrumen kemampuan berpikir kritis IPA meliputi validitas isi yang didasari dari hasil validasi oleh pendapat ahli (expert judgment) dan praktisi pendidikan untuk pembelajaran IPA. Tahapan validasi awal untuk instrumen kemampuan berpikir kritis IPA adalah validasi ahli oleh 2 orang dosen ahli dan divalidasi juga oleh 3 orang praktisi di bidang pendidikan yang berprofesi sebagai guru sekolah dasar

Hasil dari expert judgment selanjutnya dilakukan analisis untuk mendapatkan indeks ratio validitasnya dengan melakukan perhitungan Content Validity Ratio (CVR). Rubrik penskoran untuk judges menggunakan skala 3, yaitu relevan (3), kurang relevan (2),
Sebelum melakukan uji analisis dengan ANAVA-AB dan uji-t terlebih dahulu dilakukan uji normalitas dan homogenitas data. Uji normalitas data dilakukan dengan teknik KolmogorovSmirnov dan uji homogenitas data menggunakan uji Bartlet. Setelah dilakukan uji persyaratan analisis didapatkan bahwa data hasil penelitian berdistribusi normal dan homogen sehingga pengujian hipotesis dengan uji ANAVA-AB dan uji-t dapat dilakukan dan diperoleh hasil sebagai berikut.

dan tidak relevan (1). Hasil uji validitas instrumen kemampuan berpikir kritis IPA yang dikembangkan sebanyak 10 butir soal adalah valid.

Validitas instrumen keterampilan menulis meliputi validitas isi yang didasari dari hasil validasi oleh pendapat ahli (expert judgment) dan praktisi pendidikan untuk pembelajaran IPA. Tahapan validasi awal untuk instrumen keterampilan menulis IPA adalah validasi ahli oleh 2 orang dosen dan 3 orang praktisi dari guru sekolah dasar. Hasil validasi oleh pendapat ahli (expert judgment) dan praktisi pendidikan untuk pembelajaran IPA diujikan pada peserta didik yang berjumlah 60 orang dinyatakan valid.

Validitas instrumen kemampuan berpikir kritis meliputi validitas isi yang didasari dari hasil validasi oleh pendapat ahli (expert judgment) dan praktisi pendidikan untuk pembelajaran IPA. Tahapan validasi awal untuk instrumen kemampuan berpikir kritis adalah validasi ahli oleh 2 orang dosen dan 3 orang praktisi dari guru sekolah dasar. Hasil validasi oleh pendapat ahli (expert judgment) dan praktisi pendidikan untuk pembelajaran IPA diujikan pada siswa kelas $\mathrm{V}$ yang berjumlah 60 orang dinyatakan valid.

Reliabilitas instrumen keterampilan menulis dilakukan berdasarkan uji ahli dan praktisi pendidikan. Hasil perhitungan reliabilitas instrumen keterampilan menulis yang telah diperoleh akan dibandingkan 
dengan tabel kriteria reliabilitas. Reliabilitas instrumen yang berbentuk rating scale kemampuan literasi matematika diuji dengan rumus Alpha Cronbach berbantuan Microsoft Exel.

Berdasarkan hasil uji reliabilitas maka dapat disimpulkan bahwa instrumen keterampilan menulis memperoleh nilai 0,804. Data ini menunjukkan reliabilitas berada pada rentang $0,60<r 11 \leq 0,80$ atau berada pada derajat reliabilitas tinggi (baik).

Reliabilitas instrumen kemampuan berpikir kritis IPA dilakukan berdasarkan uji ahli dan praktisi pendidikan. Hasil perhitungan reliabilitas instrumen kemampuan berpikir kritis IPA yang telah diperoleh akan dibandingkan dengan tabel kriteria reliabilitas. Reliabilitas instrumen yang berbentuk rating scale kemampuan berpikir kritis IPA diuji dengan rumus Alpha Cronbach berbantuan Microsoft Excel.

Berdasarkan hasil uji reliabilitas maka dapat disimpulkan bahwa instrumen kemampuan berpikir kritis IPA memeroleh nilai 0,753. Data ini menunjukkan reliabilitas berada pada rentang $0,80<r 11 \leq 1,00$ atau berada pada derajat reliabilitas sangat tinggi (sangat baik)

Hasil analisis tingkat kesukaran soal yang dilakukan terhadap 8 butir soal pada instrumen keterampilan menulis dapat diketahui bahwa 3 butir soal termasuk kategori mudah $(37,5 \%)$, 4 butir soal termasuk kategori sedang $(50,0 \%)$, dan 1 butir soal termasuk kategori sukar (12,5\%). Hasil analisis tingkat kesukaran soal yang dilakukan terhadap 10 butir soal pada instrumen kemampuan berpikir kritis dapat diketahui bahwa 3 butir soal termasuk kategori mudah $(30,0 \%), 5$ butir soal termasuk kategori sedang $(50,0 \%)$, dan 2 butir soal termasuk kategori sukar $(20,0 \%)$.

Penelitian menggunakan model pengembangan 4-D yang terdiri dari tahap define, design, dan develop. Instrumen pengumpulan data berupa angket uji validitas dan uji praktikalitas (validitas logis), serta soal esai. Data dianalisis dengan menggunakan statistik deskriptif. Penelitian ini menghasilkan asesmen berpikir kritis yang valid dan praktis.

Pada tahap Define ini diperoleh data tentang analisis kebutuhan terhadap instrumen asesmen keterampilan menulis dan berpikir kritis pada mata pelajaran IPA SD. Fungsi analisis kebutuhan pembelajaran menurut Morison (dalam Warsita, 2011): a) Mengidentifikasi kebutuhan yang relevan dengan pekerjaan atau tugas sekarang, yaitu masalah yang mempengaruhi hasil pembelajaran. b) Mengidentifikasi kebutuhan mendesak yang terkait dengan finansial, keamanan atau masalah-masalah lain yang menggangu pekerjaan atau lingkungan pendidikan c) Menyajikan skala prioritas untuk memilih tindakan yang tepat dalam mengatatasi masalah-masalah pembelajaran. d) Memberikan data basis untuk menganalisis efektifitas kegiatan pembelajaran.

Hasil observasi menyatakan sekolah yang dipilih sebagai tempat penelitian sudah memberlakukan kurikulum 2013 yang artinya sudah mengimplementasikan 3 konsep pendidikan abad 21 (keterampilan dan pengetahuan abad 21, pendekatan saintifik, dan penilaian autentik). Materi pelajaran IPA SD kelas IV adalah materi Gaya dan Gerak pada pelajaran IPA.

Secara umum guru dan siswa sudah memiliki pengalaman tentang keterampilan menulis dan berpikir kritis meskipun pengalaman yang dimiliki hanya sebatas keterampilan menulis dan berpikir kritis. Sedangkan untuk pengalaman siswa mengerjakan soalsoal yang berhubungan dengan keterampilan keterampilan menulis dan berpikir kritis masih sangat kurang, hal ini tidak terlepas dari peranan guru dalam pelaksanaan pembelajaran. Sehingga baik guru maupun siswa secara psikologis tertarik dan termotivasi untuk mengukur keterampilan menulis dan berpikir kritis. Siswa yang memiliki keterampilan menulis dan berpikir kritis, yakni 
keadaan atau kondisi siswa yang bersemangat dalam belajar biasanya didukung oleh kondisi atau lingkungan yang peduli terhadap perkembangan belajar siswa.

Dari data di atas sebenarnya sudah terjadi sedikit kesenjangan antara tujuan implementasi kurikulum 2013 dengan kenyataan yang ada di lapangan. Guru dan siswa hanya pernah mendengar keterampilan menulis dan berpikir kritis, tanpa mereka paham apa sebenarnya keterampilan menulis dan berpikir kritis tersebut. Padahal seperti yang kita ketahui, keterampilan menulis dan berpikir kritis merupakan bagian dari kurikulum 2013, yang semestinya sudah dimasukan ke dalam rencana pelaksanaan pembelajaran dan dilaksanakan pada saat pembelajaran seperti pemberian soal-soal HOTS atau penilaian yang mengukur keterampilan itu sendiri. Dalam menjalankan kurikulum 2013 yang menuntut pendekatan scientific yang di dalamnya memuat student center, maka guru diwajibkan mengarahkan siswa untuk menguasai kemampuan berpikir tingkat tinggi yaitu kemampuan penguasaan materi dengan praktiknya yang seimbang. Ketika guru tidak mampu mengarahkan siswanya untuk menguasai kemampuan tingkat tinggi, maka dapat dibayangkan output dari sekolah tersebut tidak akan menghasilkan peserta didik yang berkompeten dan mampu bersaing seperti harapan pendidikan abad 21 .

Maka guru adalah faktor penentu keberhasilan proses pembelajaran yang berkualitas. Sehingga berhasil tidaknya pendidikan mencapai tujuan selalu dihubungkan dengan kualitas para guru. Oleh karena itu, usaha-usaha yang dilakukan dalam meningkatkan mutu pendidikan hendaknya dimulai dari peningkatan kualitas guru. Guru yang berkualitas diantaranya adalah mengetahui dan mengerti peran dan fungsinya dalam proses pembelajaran. Guru yang berkualitas selalu fleksibel mengikuti perkembangan kurikulum dan selalu terdepan dalam menyerap maupun mengimplementasikan berbagai informasiinformasi baru kepada siswanya. Guru memikul tanggung jawab utama dalam transformasi orientasi siswa dari ketidaktahuan menjadi tahu, dari ketergantungan menjadi mandiri, dari tidak terampil menjadi terampil, dengan metode-metode pembelajaran bukan lagi mempersiapkan peserta didik yang pasif, melainkan siswa berpengetahuan yang senantiasa mampu menyerap dan menyesuaikan diri dengan informasi baru dengan berpikir, bertanya, menggali, mencipta dan mengembangkan cara-cara tertentu dalam memecahkan masalah yang berkaitan dengan kehidupannya. Perubahan ini penting untuk memunculkan bentuk-bentuk pembelajaran baru yang dibutuhkan dalam mengatasi tantangan global yang kompleks. Standar baru diperlukan agar siswa kelak memiliki kompetensi yang diperlukan pada abad ke-21. Sekolah ditantang menemukan cara dalam rangka memungkinkan siswa sukses dalam pekerjaan dan kehidupan melalui penguasaan keterampilan menulis dan kemampuan berpikir kritis, pemecahan masalah yang fleksibel, berkolaborasi dan berinovasi.

Terkait dengan Kurikulum 2013 terdapat beberapa hal yang perlu diperhatikan di dalam implementasinya. Permendikbud No. 65 Tahun 2013 menyebutkan terdapat 4 komponen yang perlu diperhatikan seperti (a) mempersiapkan proses pengajaran dan pembelajaran, (b) melaksanakan pengajaran dan pembelajaran, (c) mengevaluasi dan melaksanakan asesmen terhadap proses pembelajaran, dan (d) membantu proses pembelajaran. Keempat komponen tersebut harus diintegrasikan di dalam pengimplementasian Kurikulum 2013 yang wajib dilaksanakan oleh guru.

Menggunakan berbagai bentuk asesmen maka dapat mengetahui proses pembelajaran siswa, sikap, kebiasaan, dan hal-hal lainnya terkait 
dengan pembelajaran siswa. Jadi dengan menggunakan instrumen asesmen keterampilan menulis dan berpikir kritis maka akan dapat mengetahui kognitif siswa maupun sikap siswa. Serta dapat mengetahui sejauh mana ketercapaian implementasi kurikulum 2013.

Pada tahap Design, dilakukan perancangan instrumen dengan mengacu pada kriteria secara kualitatif maupun secara kuantitatif guna mendapatkan design instrumen keterampilan menulis dan berpikir kritis yang baik dan benar. Langkah pertama yang dilaksanakan adalah menentukan tes acuan patokan yang disusun berdasarkan spesifikasi tujuan pembelajaran dan analisis siswa, kemudian selanjutnya disusun kisi-kisi tes. Kisi-kisi adalah suatu format atau matriks yang memuat kriteria tentang soal-soal yang diperlukan atau yang hendak disusun. Kisi-kisi juga dapat diartikan test blue-print atau table of specification yang merupakan deskripsi kompetensi dan materi yang akan diujikan. Wujudnya adalah sebuah tabel yang memuat tentang perperincian materi dan tingkah laku beserta imbangan/proporsi yang dikehendaki oleh penilai. Tujuan penyusunan kisi-kisi adalah untuk menentukan ruang lingkup dan sebagai petunjuk dalam menulis soal Kisi-kisi dibuat dengan matriks yang terdiri dari dua jalur, yaitu kolom dan baris. Kisi-kisi adalah format yang berupa matriks yang memuat informasi tentang suatu soal dan dijadikan pedoman untuk menulis soal atau merakit soal menjadi seperangkat tes.

Dengan demikian jelas bahwa fungsi kisi-kisi di sini adalah sebagai pedoman dalam penulisan dan perakitan tes. Kisi-kisi yang baik harus memenuhi persyaratan: (1) mewakili isi kurikulum yang akan diujikan, (2) komponen-komponennya rinci, jelas, dan mudah dipahami, (3) soal-soal yang direncanakan dimungkinkan dapat dibuat sesuai dengan indikator yang direncanakan dalam kisi-kisi itu. Keterampilan berpikir kritis terdiri dari 5 aspek dan setiap aspek terdiri dari beberapa indikator, setiap indikator terdapat 2 soal yang disesuaikan dengan materi pelajaran IPA kelas IV SD. Keterampilan menulis terdiri dari 1 aspek yang terdiri dari 8 indikator, total jumlah soal keterampilan menulis sebanyak 1 soal. Untuk tes keterampilan menulis dan kemampuan berpikir kritis menggunakan tes non objektif atau disebut pula sebagai soal uraian/soal esai. Tes uraian dipilih karena dapat mengembangkan kemampuan berpikir tingkat tinggi. Dalam tes uraian (nonobjektif) ini siswa seringkali diminta untuk mengorganisasikan jawaban pertanyaannya dalam bentuk baru atau bahasanya sendiri. Sedangkan keterampilan menulis menggunakan menggunakan non tes berupa lembar observasi. Seperti pada tes lain, untuk mendapatkan soal tes uraian yang baik, perlu direncanakan secara matang. Paling tidak peneliti yang membuat soal harus memahami atau mengingat kembali prinsip-prinsip penilaian, dan mengingat kembali prosedur pengembangan tes secara umum.

Secara umum perencanaan itu mencakup: (1) Merumuskan tujuan tes, untuk apa tes itu dilakukan. (2) Mengkaji/ menganalisis: pokok bahasan /topik/tema/konsep, buku sumber, rencana pembelajaran/satuan pelajaran, dan materi-materi pelajaran mana yang cocok untuk dibuat dengan soal uraian. (3) Membuat kisi-kisi (4) Penulisan soal disertai pembuatan kunci jawaban dan pedoman penskoran (5) Penelaahan kembali rumusan soal (oleh sendiri atau orang lain). Dalam menulis soal bentuk uraian, penulis soal harus mempunyai gambaran tentang ruang lingkup materi yang ditanyakan dan lingkup jawaban yang diharapkan, kedalaman dan panjang jawaban, atau rincian jawaban yang mungkin diberikan oleh siswa. Dengan adanya batasan ruang lingkup, kemungkinan terjadinya ketidakjelasan soal dapat dihindari, serta dapat mempermudah pembuatan kriteria atau pedoman penyekoran. Karena itu kaidah umum yang terpenting dalam menulis 
soal bentuk uraian adalah, segera tulis kunci jawaban atau pokok-pokok jawaban yang mungkin diberikan oleh siswa beserta kriteria atau rentang skor yang mungkin diberikan, begitu selesai menulis soal. Kaidah khusus penulisan soal bentuk uraian adalah menetapkan kriteria tes yang baik secara kuantitatif, peneliti melakukan kajian beberapa literatur. Yang dimaksud dengan persyaratan kualitatif dalam menyusun soal uadalah aspek substantive (materi), aspek konstruksi, dan aspek bahasa. Secara kuantitaif, instrumen yang dirancang perlu memenuhi kriteria tes yang baik berdasarkan parameterparameter butir soal. Parameterparameter butir soal berbentuk uraian ada dua, yaitu tingkat kesukaran dan daya beda. Meskipun seluruh soal sudah di uji tingkat ke validan dan tingkat reliabilitasnya, bukan berarti soal sudah layak pakai, karena kita tidak tahu bagian soal mana yang sudah dirasa pernah dipelajari dan juga bagian soal mana yang tergolong mudah maupun sulit, yang mana hal tersebut mempengaruhi terhadap kualitas soal.

Pada tahap develop, langkah yang dilakukan adalah membuat instrumen (constructing test) dan validasi isi oleh pakar (expert appraisal). Validasi instrumen keterampilan menulis dan berpikir kritis meliputi validitas isi dan validitas butir instrumen. Validitas isi dilakukan oleh lima orang pakar ahli pendidikan. Dalam Standar untuk Tes Pendidikan dan Psikologi (American Educational Research Association, American Psychological Association \& National Council of Measurement in Education, 1985) "bukti validitas terkait konten" didefinisikan sebagai "bukti yang menunjukkan sejauh mana isi tes sesuai dengan tujuan yang dimaksudkannya. Bukti tersebut digunakan untuk menetapkan bahwa pengujian tersebut mencakup contoh yang representatif atau kritis dari domain konten yang relevan dan isinya tidak termasuk konten di luar domain tersebut". Validitas isi merupakan validitas yang diestimasi lewat pengujian terhadap kelayakan atau relevansi isi tes melalui analisis rasional oleh panel yang berkompeten atau melalui expert judgement (penilaian ahli). Validitas isi atau content validity memastikan bahwa pengukuran memasukkan sekumpulan item yang memadai dan mewakili yang mengungkap konsep. Semakin item skala mencerminkan kawasan atau keseluruh konsep yang diukur, semakin besar validitas isi. Atau dengan kata lain, validitas isi merupakan fungsi seberapa baik dimensi dan elemen sebuah konsep yang telah digambarkan (Sekaran, 2006). Hasil validitas pakar I, pakar II, pakar III, pakar IV dan pakar V adalah tes keterampilan menulis berada pada kategori tinggi sebesar 1 dan kemampuan berpikir kritis berada pada kategori tinggi sebesar 1 . Secara umum kesimpulan hasil uji validasi isi instrumen dari para ahli dan praktisi yaitu valid sehingga bisa dikatakan bahwa faktor-faktor yang merupakan bagian dari instrumen tersebut tidak meyimpang dari fungsi instrumen.

Pada tahap Disseminate, peneliti melaksanakan uji coba butir instrumen. Pengujian butir tes dimaksudkan untuk menilai kemampuan tiap-tiap butir. Setelah melaksanakan uji validitas butir insrumen, langkah selanjutnya adalah melaksanakan uji reliabilitas tes instrumen. Hasil uji reliabilitas keterampilan menulis IPA memperoleh hasil $r 11$ sebesar 0,86 yang berkategori sangat tinggi. Hasil uji reliabilitas kemampuan berpikir kritis memperoleh r11 sebesar 0,74 yang berkatagori tinggi. Hasil respon guru terhadap keterlaksanaan instrumen asesmen keterampilan menulis IPA dan kemampuan berpikir kritis adalah sangat praktis pada aspek afektif dan praktis pada aspek interaktif, menarik, efisien dan kreatif. Sedangkan hasil respon siswa terhadap keterlaksanaan instrumen asesmen keterampilan menulis dan berpikir kritis adalah praktis pada semua aspek yaitu aspek afektif, interaktif, menarik, efisien dan kreatif. Kepraktisan sebuah alat evaluasi lebih menekankan pada tingkat efisiensi dan 
efektivitas alat evaluasi tersebut, beberapa kriteria yang dikemukakan oleh Gerson, dkk dalam mengukur tingkat kepraktisan, diantaranya adalah: (a) Waktu yang diperlukan untuk menyusun tes tersebut. (b) Biaya yang diperlukan untuk menyelenggarakan tes tersebut. (c) Waktu yang diperlukan untuk melaksanakan tes (d) Tingkat kesulitas menyusun tes (e) Tingkat kesulitan dalam proses pemeriksaan tes (f) Tingkat kesulitan melakukan intrepetasi terhadap hasil tes.

\section{PENUTUP}

Berdasarkan hasil penelitian dan pembahasan penelitian pengembangan dapat ditarik kesimpulan bahwa Penelitian pengembangan ini menghasilkan pada instrumen pertama yaitu keterampilan menulis dengan mengembangkan soal sebanyak 1 butir. Berdasarkan hasil dari perhitungan CVR, didapatkan 1 soal yang valid. Instrumen kedua yaitu kemampuan berpikir kritis IPA berupa soal uraian sebanyak 10 butir. Selanjutnya dilakukan analisis uji validitas isi untuk instrumen kemampuan berpikir kritis IPA pada siswa kelas IV SD menggunakan CVR. Berdasarkan hasil perhitungan CVR didapatkan 10 butir instrumen yang valid dan tidak terdapat instrumen yang tidak valid.

Hasil uji validitas menunjukkan soal valid (secara logis dan empiris), reliabilitas soal tinggi, dan tingkat kesukaran soal yang bervariasi. Berdasarkan hal tersebut, dapat disimpulkan telah dihasilkan instrumen keterampilan menulis dan kemampuan berpikir kritis yang valid secara logis dan empiris, praktis, dan reliabel.

Berdasarkan simpulan yang telah dikemukakan, maka peneliti merekomendasikan hal-hal sebagai berikut, (1) penelitian pengembangan ini diharapkan dapat meningkatkan keterampilan menulis dan berpikir kritis IPA untuk mengembangkan dirinya dan meraih keberhasilan belajar yang optimal, (2) penelitian ini diharapkan dapat dijadikan pedoman bagi guru untuk merancang pengembangan keterampilan menulis dan berpikir kritis IPA siswa, (3) Penelitian ini diharapkan dapat kontribusi sehigga menajdi acuan pengembangan instrument-instrumen yang berkaitan dengan pendidikan sehingga dapat menacapai tujuan pendidikan secara optimal.

\section{DAFTAR RUJUKAN}

Febriyanti, A. L., Harsiati, T., \& Dermawan, T. (2017). Pengembangan Instrumen Asesmen Menulis Kreatif Cerita Fantasi Untuk Siswa Kelas VII SMP. Jurnal Pendidikan: Teori, Penelitian, dan Pengembangan, 2(10), 1399-1408.

Istiyono, E., Mardapi, D., \& Suparno, S. (2014). Pengembangan Tes Kemampuan Berpikir Tingkat Tinggi Fisika (PysTHOTS) Peserta Didik SMA. Jurnal Penelitian dan Evaluasi Pendidikan, 18(1), 1-12.

Khaerunnnisa, E., \& Pamungkas, A. S. (2018). Pengembangan Instrumen Kecakapan Matematis Dalam Konteks Kearifan Lokal Budaya Banten Pada Materi Bangun Ruang Sisi Datar. Kreano, Jurnal Matematika Kreatif-Inovatif, 9(1), 17-27.

Kusairi, S. (2012). Analisis Asesmen Formatif Fisika SMA Berbantuan Komputer. Jurnal Penelitian dan Evaluasi Pendidikan, 16, 68-87.

Qostantia, L. N. (2016). Susahkah Menulis Cerita Fabel? Prosiding Seminar Nasional Appi-Bastra: Asosiasi Pendidik dan Peneliti Bahasa dan Sastra, Surabaya, 24 September.

Rahayuni, G. (2016). Hubungan Kemampuan Berpikir Kritis dan Literasi Sains Pada Pembelajaran IPA Terpadu dengan Model PBM dan STM. Jurnal penelitian dan Pembelajaran IPA, 2(2), 131-146.

Reta, I. K. (2012). Pengaruh Model Pembelajaran Berbasis Masalah 
Terhadap Keterampilan Berpikir Kritis Ditinjau Dari Gaya Kognitif Siswa. Jurnal Pendidikan dan Pembelajaran IPA Indonesia, 2(1).

Rosyida, F., Zubaidah, S., \& Mahanal, S. (2016). Memberdayakan Keterampilan Berpikir Kritis dengan Model Pembelajaran Remap TmPS (Reading Concept Map Timed Pair Share). Proceeding Biology Education Conference: Biology, Science, Enviromental, and Learning, 13(1), 209-214.

Sekaran, U. (2006). Research Methods For Business: Metodologi Penelitian Untuk. Bisnis (4 ed.). Jakarta: Salemba Empat.

Setiawan, H., \& Sa'dijah, C. (2017). Pengembangan Instrumen Asesmen Autentik Kompetensi Pada Ranah Keterampilan Untuk Pembelajaran Tematik Di Sekolah Dasar. Jurnal Pendidikan: Teori, Penelitian, dan Pengembangan, 2(7), 874-882.

Sudijono, A. (2011). Pengantar Statistik
Pendidikan. Jakarta: Rajawali Press.

Sugiyono. (2015). Metode Penelitian Pendidikan: Pendekatan Kuantitatif, Kualitatif, dan $R$ \& $D$. Bandung: Alfabeta.

Trianto. (2010). Mendesain Model Pembelajaran Inovatif-Progesit: Konsep Landasan, dan Implementasinya pada Kurikulum Tingkat Satuan Pendidikan (KTSP). Surabaya: Kencana Prenada Media Grup.

Warsita, B. (2011). Pendidikan Jarak Jauh. Bandung: PT Remaja Rosdakarya.

Widoyoko, E. P. (2014). Teknik Penyususnan Instrumen Penelitian. Yogyakarta: Pustaka Pelajar.

Yen, T. S., \& Halili, S. H. (2015). Effective Teaching of Higher-Order Thinking (HOT) in Education. The Online Journal of Distance Education and e-Learning, 3(2), 41-47. 